\title{
BLOCKCHAIN TECHNOLOGY APPLICATION AREAS IN THE SMART CITY INFORMATION SYSTEMS
}

\author{
Zoran Ćirić ${ }^{1}$ \\ Otilija Sedlak ${ }^{2}$ \\ Stojan Ivanišević ${ }^{3}$
}

DOI: https://doi.org/10.31410/ITEMA.2019.209

\begin{abstract}
By cross-referencing benefits of blockchain technologies and critical issues and weak points of smart city information systems, one may conclude that blockchain systems are just the right solution for smart city information systems. However, this may not be true and applicable generally let alone universally. Traditional information system requires an increased level of security and availability of service when they have to be exposed to the public and used by the tens of thousands of inhabitants within a city. On the other hand, blockchain technologies offer a completely new combination of technologies to solve security and reliability issues as well as the availability of service and failsafe tolerance. The scope of this work is to analyse literature as well as available use cases to detect areas of a successful application for information systems that are using blockchain in the smart city.
\end{abstract}

Keywords: Blockchain, Smart City, Feasibility Study, Information Systems.

\section{INTRODUCTION}

$\mathrm{T}$ his paper elaborates potential applications of blockchain technology found within the scientific literature. In an attempt to create analysis that is easier to understand, potential applications are divided by the component of the smart city that they are related to. Accepting blockchain technologies and exploring ways to apply these technologies to addressing challenges in smart cities is a research direction and represents a new area that has not been sufficiently explored through the prism of scientific research, because blockchain technologies were recently adopted with creation of Ethereum Enterprise Alliance in 2017. The result of the research in this paper is to show the possibility for improvement of sustainability within a smart city with the application of blockchain technology and to search for a scientific founded framework for the application of blockchain technologies in the smart cities.

In scientific literature, blocking technology has not been sufficiently explored since its beginning is related to 2008 [2], with wider acceptance by large corporations only in 2017 [1]; therefore, there are not enough scientific studies of the application of this technology in practice. Governments are very cautious with application for these technologies and far more carefully that real sector. Because smart cities are ruled by the government sector that is naturally more conservative, real-life applications within e-Government and other government-related smart city aspects are scarcer.

\footnotetext{
1 University of Novi Sad, Faculty of Economics Subotica, Segedinski put 9-11, Subotica, Serbia

2 University of Novi Sad, Faculty of Economics Subotica, Segedinski put 9-11, Subotica, Serbia

3 JKP Informatika Novi Sad, Bul. cara Lazara 3, Novi Sad, Serbia
} 


\section{BLOCKCHAIN TECHNOLOGY}

Blockchain technology, which became known primarily thanks to bitcoin (Bitcoin), is a type of distributed system technology further referred to as Distributed Ledger Technology (DLT), which is defined as a ,distributed, shared, encrypted database that serves as irreversible and non-recoverable (non-corrupt) information repository". [1] When blockchain technology is used to create a platform, the product is a digital platform that stores and verifies the entire transaction history between its users anywhere on the network. From a technical point of view, blockchain is a „database consisting of chronologically arranged series of transactions known as blocks" about which each proposed transaction must be checked with the certainty and integrity of that particular block ,.. [2]

Once the information is entered, it can never be deleted [3]. Block technology is described in the literature as a database and as a network equipped with a built-in security system and internal integrity. [4]

\section{POTENTIAL BLOCKCHAIN TECHNOLOGY APPLICATIONS IN THE SMART CITY}

In order to start the analysis of potential blockchain applications in the smart cities, it is necessary to tie application areas with smart city components. One of the known definitions of the smart city (ITU) is: „A smart and sustainable city is an innovative city that has extensive use of information technology using them to develop the quality of life level, city administration, by taking into the account the needs of current and future generations in the same way as it takes into account economic, social and environmental aspects". [5]

Between all views in contemporary scientific literature list of smart city components from Lombardi et al. [6] have been taken as starting point. According to this group of authors, smart city components are:

1. Smart economy - viewed as industry as an aspect of urban life;

2. Smart citizens - knowledge and human capital;

3. Smart governance - e-Government and open data;

4. Smart mobility - logistics and infrastructures;

5. Smart environment - sustainability;

6. Smart living - livability and quality of life and security.

A brief literature review is examining examples of the application of blockchain technology in order to contribute to the sustainability of a smart city as well as any limiting circumstances related to the application.

$\begin{array}{ll}\text { Component } & \text { Potential applications: } \\ \begin{array}{l}\text { Smart economy } \\ \text { - industry }\end{array} & \text { Blockchain-based sharing services: The sharing economy can be defined as an economic/ } \\ & \text { social model that broad sectors of the population can employ to collaboratively make use } \\ & \text { of under-utilized assets, in which supply and demand are interacting for the supply side to } \\ & \text { directly provide products/services. The overall aim of a sharing business, which can be both } \\ & \text { profit-oriented and non-profit oriented, is to improve the use of under-utilized assets and } \\ & \text { reduce transaction costs. [7],[8],[9] } \\ & \text { Fintech industry and crypto economy: The key advantage of this technology lies in the fact that it } \\ & \text { enables the establishment of secured, trusted, and decentralized autonomous ecosystems for vari- } \\ & \text { ous scenarios, especially for better us age of the legacy devices, infrastructure, and resources. [10] }\end{array}$




\begin{tabular}{|c|c|}
\hline Component & Potential applications: \\
\hline \multirow[t]{3}{*}{$\begin{array}{l}\text { Smart citizens } \\
\text { - knowledge and } \\
\text { human capital }\end{array}$} & $\begin{array}{l}\text { Digital identity: blockchain solutions provide digital identities based on cryptography and } \\
\text { anonymity. Identity verification and authentication technologies, as one of the applications } \\
\text { of blockchain-based solutions - and the focus of our own efforts at SecureKey Technologies } \\
\text { - have been critical components in service delivery in both sectors due to their power to in- } \\
\text { crease trust between citizens and the services they access. [17],[18] }\end{array}$ \\
\hline & $\begin{array}{l}\text { Smart Health: system for sharing patients' data between institutions in safe and anonymous } \\
\text { manner. [19] }\end{array}$ \\
\hline & $\begin{array}{l}\text { Digital content distribution: The blockchain-based digital content distribution system was } \\
\text { developed. Decentralized and pear-to-pear authentication mechanism can be considered as } \\
\text { the ideal rights management mechanism. The blockchain has the potential to realize this } \\
\text { ideal content distribution system. [20] }\end{array}$ \\
\hline $\begin{array}{l}\text { Smart g } \\
-\mathrm{e}-\mathrm{Gov}\end{array}$ & $\begin{array}{l}\text { E-government: a group of authors discuss use of blockchain technology as a platform for } \\
\text { various applications in e-Government and furthermore as an emerging support infrastruc- } \\
\text { ture by showing that blockchain technology demonstrates a potential as well as discussing } \\
\text { limitation factors. [21],[22] }\end{array}$ \\
\hline \multirow[t]{5}{*}{$\begin{array}{l}\text { Smart mobility } \\
\text { - logistics and } \\
\text { infrastructures }\end{array}$} & $\begin{array}{l}\text { Supply chain management: Blockchain technology promises overpowering trust issues and } \\
\text { allowing trustless, secure and authenticated system of logistics and supply chain informa- } \\
\text { tion exchange in supply networks. [11] }\end{array}$ \\
\hline & $\begin{array}{l}\text { Transportation: Blockchain can be used to build an intelligent, secure, distributed and au- } \\
\text { tonomous transport system. [12] }\end{array}$ \\
\hline & $\begin{array}{l}\text { Electric vehicle charging: shared changing for electric vehicles and biding for the energy. } \\
{[13],[14]}\end{array}$ \\
\hline & $\begin{array}{l}\text { Logistics - a group of authors made a great review of potential applications of blockchain } \\
\text { in logistics. [15] }\end{array}$ \\
\hline & $\begin{array}{l}\text { Food supply management: blockchain solutions provide tracking of goods prom production } \\
\text { to final consumers. [16] }\end{array}$ \\
\hline \multirow{2}{*}{$\begin{array}{l}\text { Smart } \\
\text { environment } \\
\text { - sustainability }\end{array}$} & $\begin{array}{l}\text { Sustainable supply chains - Sustainable, and especially green, supply chains can benefit from } \\
\text { blockchain technology, but there are also caveats. [23] }\end{array}$ \\
\hline & $\begin{array}{l}\text { Smart grid - Emerging markets must attract significant international financing to meet their } \\
\text { goals for mitigating carbon pollution and increasing access to clean, affordable, reliable, and } \\
\text { resilient energy. The authors* of this note examine how blockchain technology can - if paired } \\
\text { with smart, interconnected devices - promote needed investments by both improving investment } \\
\text { processes and promoting the adoption of modern energy systems and business models. [26] }\end{array}$ \\
\hline \multirow[t]{2}{*}{$\begin{array}{l}\text { Smart living } \\
\text { - livability and } \\
\text { quality of life and } \\
\text { security }\end{array}$} & $\begin{array}{l}\text { Public safety - The idea of smart cities is developing extremely rapidly, integrating smart grid, } \\
\text { services, building, house and appliances, these subsystems must be able to interact, connect, } \\
\text { and control remotely, collaboratively, to achieve a better quality of life, sustainability, energy } \\
\text { saving, social and economic development. The widespread of Smart City depends heavily on } \\
\text { the capability of users to understand and handle the ICT, IoT and BC. [24] }\end{array}$ \\
\hline & $\begin{array}{l}\text { Within a permissioned blockchain network, a microservices based security mechanism is in- } \\
\text { troduced to secure data access control in a smart public safety system. [25] }\end{array}$ \\
\hline
\end{tabular}

\section{CONCLUSION AND FURTHER RESEARCH}

The review of the contemporary scientific literature shows that the scientific literature discusses potential applications of smart cities within specific subcomponents of the smart city. Improved privacy, security, availability and heterogeneous architectures correspond with strong points of blockchain technology, because blockchain based systems provide strong security together with total anonymity; their distributed nature also increase availability and finally their nature is interoperable. Because of these strong points of blockchain technologies, a greater number of potential applications and subsequently real-life applications and scientific discussions and studies exist in relation to the economy, mobility and supply chain management and e-Government. Literature view on the potential application of blockchain technology that increase envi- 
ronmental sustainability and main contribution of blockchain to smart environment is perceived as contribution in sustainability of information systems within smart cities, supply chains improvement and new business models in energy systems.

In scientific literature, papers are dealing with the applications of blockchain technology to increase the sustainability of smart cities, as shown in the literature review. The available scientific literature, however, does not analyse these applications through a prism of smart city components, but rather through more narrower application areas.

However, the authors did not find any working framework for the implementation of information systems projects (IS) based on these technologies in the scientific literature. According to the authors, it is necessary to mark the areas of application of this technology in smart cities and to continue to explore ways of applying to define the success factors and results indicators for the implementation of the IS projects based on block technology.

In order to conduct further study of this subject applications of blockchain technologies in smart cities should be divided into potential and theoretical found within scientific literature and real-life application within existing smart cities. Further study of successfully applied blockchain information systems needs to be conducted in order to identify smart city components and particular subsystems where blockchain technologies showed improved results and increased sustainability compared to traditional information systems.

\section{REFERENCES}

[1] Wright, Aaron and De Filippi, Primavera, Decentralized Blockchain Technology and the Rise of Lex Cryptographia (March 10, 2015), available at http://ssrn.com/abstract=2580664.

[2] Wessel quoting BoE Blockchain Technology, Sutardja Center for Entrepreneurship \& Technology

[3] Embracing Disruption - Tapping the Potential of Distributed Ledgers to Improve the PostTrade Landscape, Deposit Trust \& Clearing Corporation (January 2016), available athttp:// www.dtcc.com/ /media/Files/PDFs/DTCC-Embracing-Disruption.pdf

[4] Pilkington, Marc, "Blockchain Technology: Principles and Applications," page 15 (citing Kwon, J. (2014). Tendermint: Consensus without Mining. White paper.)

[5] http://www.itu.int/en/ITU-T/ssc/Pages/info-ssc.aspx (16.2.2017)

[6] P. Lombardi, S. Giordano, H. Farouh, and W. Yousef, "Modelling the Smart City Performance", Innovation: The European Journal of Social Science Research25: 2 (2012) 137 - 149.

[7] Sun, J., Yan, J. \& Zhang, K.Z.K. Blockchain-based sharing services: What blockchain technology can contribute to smart cities. Financ. Innov. 2, 26 (2016). https://doi.org/10.1186/ s40854-016-0040-y

[8] Gori P, Parcu PL, Stasi ML (2015) Smart Cities and Sharing Economy, vol 96, Robert Schuman Centre for Advanced Studies Research Paper No. RSCAS

[9] Steve Huckle, Rituparna Bhattacharya, Martin White, Natalia Beloff, Procedia Computer Science Volume 98, 2016, Pages 461-466

[10] Y. Yuan and F. Wang, „Blockchain and Cryptocurrencies: Model, Techniques, and Applications," in IEEE Transactions on Systems, Man, and Cybernetics: Systems, vol. 48, no. 9, pp. 1421-1428, Sept. 2018.doi: 10.1109/TSMC.2018.2854904

[11] Dujak D., Sajter D. (2019) Blockchain Applications in Supply Chain. In: Kawa A., Maryniak A. (eds) SMART Supply Network. EcoProduction (Environmental Issues in Logistics and Manufacturing). Springer, Cham 
[12] Pradip Kumar Sharma, Seo Yeon Moon, and Jong Hyuk Park ,Block-VN: A Distributed Blockchain Based Vehicular Network Architecture in Smart City, J Inf Process Syst, Vol.13, No.1,pp.184 195, February, 2017 ISSN 1976-913X (Print) https://doi.org/10.3745/ JIPS.03.0065

[13] F. Knirsch, A. Unterweger, and D. Engel, "Privacy-preserving blockchain-based electric vehicle charging with dynamic tariff decisions," Comput. Sci. Res. Develop., vol. 33, nos. 1-2, pp. 71-79, 2017.

[14] J. Kang et al., "Enabling localized peer-to-peer electricity trading among plug-in hybrid electric vehicles using consortium blockchains," IEEE Trans. Ind. Informat., vol. 13, no. 6, pp. 3154-3164, Dec. 2017.

[15] Dobrovnik, M.; Herold, D.M.; Fürst, E.; Kummer, S. Blockchain for and in Logistics: What to Adopt and Where to Start. Logistics 2018, 2, 18.

[16] Tian, F. An agri-food supply chain traceability system for China based on RFID \& blockchain technology. In Proceedings of the 2016 13th International Conference on Service Systems and Service Management (ICSSSM), Kunming, China, 24-26 June 2016.

[17] Wolfond, G.: A blockchain ecosystem for digital identity: improving service delivery in Canada's public and private sectors. Technol. Innov. Manag. Rev.7(10), 35-40 (2017)

[18] A.H.Mohsin, A.A.Zaidan, B.B.Zaidan, O.S.Albahri, A.S.Albahri, M.A.Alsalem, K.I.Mohammed, Blockchain authentication of network applications: Taxonomy, classification, capabilities, open challenges, motivations, recommendations and future directions, Computer Standards \& Interfaces, Volume 64, May 2019, Pages 41-60

[19] K. Peterson, R. Deeduvanu, P. Kanjamala, and K. Boles. (2016). A Blockchain-Based Approach to Health Information Exchange Networks. [Online]. Available: http://www.colleaga.org/sites/default/files/12-55-blockchain-based-approach-final.pdf

[20] J. Kishigami, S. Fujimura, H. Watanabe, A. Nakadaira and A. Akutsu, „The Blockchain-Based Digital Content Distribution System," 2015 IEEE Fifth International Conference on Big Data and Cloud Computing, Dalian, 2015, pp. 187-190. doi: 10.1109/BDCloud.2015.60

[21] Olnes and Jansen, 2017 S. Ølnes, A. Jansen, Blockchain technology as s support infrastructure in e-Government International Conference on Electronic Government, Springer (2017), pp. 215-227

[22] F. Rizal Batubara, Jolien Ubacht, and Marijn Janssen. 2018. Challenges of blockchain technology adoption for e-Government: a systematic literature review. In Proceedings of the 19th Annual International Conference on Digital Government Research: Governance in the Data Age ('18). Association for Computing Machinery, New York, NY, USA, Article 76, 1-9. DOI: https://doi.org/10.1145/3209281.3209317

[23] Kouhizadeh, M.; Sarkis, J. Blockchain Practices, Potentials, and Perspectives in Greening Supply Chains. Sustainability 2018, 10, 3652.

[24] C. Lazaroiu and M. Roscia, ,Smart district through IoT and Blockchain,” 2017 IEEE 6th International Conference on Renewable Energy Research and Applications (ICRERA), San Diego, CA, 2017, pp. 454-461. doi: 10.1109/ICRERA.2017.8191102

[25] R. Xu, S. Y. Nikouei, Y. Chen, E. Blasch and A. Aved, „BlendMAS: A Blockchain-Enabled Decentralized Microservices Architecture for Smart Public Safety," 2019 IEEE International Conference on Blockchain (Blockchain), Atlanta, GA, USA, 2019, pp. 564-571. doi: 10.1109/Blockchain.2019.00082

[26] Miller, Douglas; Mockel, Peter. 2018. Using Blockchain to Enable Cleaner, Modern Energy Systems in Emerging Markets. EMCompass; Note 61. International Finance Corporation, Washington, DC. International Finance Corporation. https://openknowledge.worldbank. org/handle/10986/31200 License: CC BY-NC-ND 3.0 IGO. 